\title{
Mortality from Lung Cancer and Other Causes among Workers in an Asbestos Textile Factory
}

\author{
J. F. KNOX, S. HOLMES, R. DOLL, and I. D. HILL \\ From Turner Brothers Asbestos Co. Ltd., Rochdale, and the Medical Research Council's Statistical Research Unit, \\ University College Hospital Medical School, London, W.C.I.
}

An account is given of work in an asbestos textile factory and of the steps taken to reduce exposure to dust since the introduction of the Asbestos Industry Regulations in I93I.

Measurements of the amount of dust to which men were exposed in the scheduled areas have been made by various methods since 195I, but the data obtained by these methods are not directly comparable. Measurements made since 1960 show that the mean yearly dust level has been fairly constant from year to year and has varied from place to place between $I$ and 8 particles ( 5 to 100 microns long and at least three times as long as they were wide) per c.c. of air.

Chrysotile was used predominantly in the factory, but small amounts of crocidolite were also processed at all relevant periods.

Death rates have been recorded for all the 256 men who were employed for at least 20 years in the scheduled areas since the first man completed 20 years' exposure in 1916, and for the 538 men and 220 women who were employed for at least Io years in the scheduled areas but were never employed in these areas before 1933 .

The results show a substantially increased mortality for men who were exposed for 10 or more years before 1933 ( 48 deaths from all causes against $17 \cdot 1$ expected).

The increased mortality among these men can be accounted for by an increased mortality from cancer of the lung ( 12 deaths against $\mathrm{I} \cdot 2$ expected) and from diseases of the respiratory and circulatory systems associated with asbestosis.

Men employed before 1933, but for less than Io years, showed an increased mortality from lung cancer (5 deaths against 2.6 expected), but no significant increase from other causes. Men and women who were exposed only since January I, I933, have had a mortality experience close to the national average.

Analysis of the trends in mortality shows (I) a decrease in mortality from lung cancer and other deaths associated with asbestosis with reduction in length of employment before 1933, and (2) an increase in mortality from lung cancer and other deaths without asbestosis with age.

Twenty-three cases of lung cancer occurred in men who had been employed in the scheduled areas for at least 20 years. One was regarded as a pleural mesothelioma and the rest (approximately 18 in excess of expected) appear to have been ordinary bronchial carcinomas.

Four other mesotheliomas have been diagnosed since 1963, all in men and women with less than Io years' exposure, one with only seven months' exposure, and one in a man who had been employed in the scheduled areas only since 1937.

The results provide grounds for believing that the occupational hazard of bronchial carcinoma has been largely eliminated, but the data are insufficient to estimate the extent of the risk which may remain.

Many studies of the mortality of asbestos workers have been reported in recent years and it has been

Received for publication March 22, 1968.

Requests for reprints to Dr. R. Doll, Medical Research Council's Statistical Research Unit, University College Hospital Medical School, II5 Gower Street, London, W.C.I. shown that some groups of workers have suffered substantial risks of disability and death from cardiorespiratory disease secondary to asbestosis and from bronchial carcinoma and pleural and peritoneal mesothelioma (New York Academy of Sciences, 1965; Gilson, 1966). In one such study Doll (1955) reported the mortality in a group of 113 men who had worked for at least 20 years in the 
'scheduled areas' of a large asbestos textile factory. In that study the mortality experience was reported to the end of 1953. Subsequently the period of observation was extended to the end of $196 \mathrm{I}$ and the scope was broadened to include men and women who had been employed since 1933 and had worked in the 'scheduled areas' for at least ro years (Knox, Doll, and Hill, 1965; Hill, Doll, and Knox, 1966).

In the present study we have extended the period of observation to the end of June 1966, added further workers who have qualified for inclusion in the defined groups, and examined the trends in mortality attributed to different causes with age and with the duration and period of exposure. We also report, in relation to these findings, the extent to which it has been possible to limit exposure to asbestos dust in the factory.

\section{Places of Work}

In an asbestos textile factory the sequence of operations proceeds from the receipt of the raw asbestos fibres to the finished textile product in woven or plaited form. The stages are:

(I) Fiberizing The raw asbestos, which has already been prepared at the mines by milling the rock, screening, and separating the fibres by air currents, arrives in bags. These are opened; the fibres are blended, and the fibre bundles are broken down further in enclosed drum-like fiberizing machines with rotary metal beaters. The fibres are then bagged again for transmission to the next process.

(2) Carding The formless mass of fibrous material is converted into a gossamer-like web which is divided into tapes and rubbed into sliver consisting of strands of short fibres made parallel to each other $(0.7$ to $1.0 \mathrm{~cm}$. in length). Much dust is produced, and ventilation at a rate of approximately $2,500 \mathrm{cu}$. $\mathrm{ft}$. of air per minute ( $7 \mathrm{I} \mathrm{m}^{3}$ per minute) per carding machine is required to carry it away through ducts, a rate which produced the levels of fibre count at the front of the machine that are shown in the last two columns of Table I. Different grades of sliver are produced, some of which are used in other manufacturing processes without further preparation.

(3) Spinning Most sliver is spun into yarn.

(4) Weaving Preparations of warp (beaming) and of weft (pirn winding) are preliminary to weaving on looms. A variety of woven materials are produced from yarns ranging from fine tapes (listing weaving) to wide cloths and including webbing and brake linings.

(5) Plaiting Ropes are produced of different specification which are sometimes impregnated with graphite or other lubricant for the manufacture of packings.

'Scheduled areas' are the parts of the factory to which the regulations for the asbestos industry apply (Asbestos Industry Regulations, I93I). They comprise areas for the operation of crushing and opening, textile processes, insulation fabrication, mattress making or repairing, all sawing and grinding, and the cleaning of chambers or appliances for asbestos dust collection.

The report by Merewether and Price (1930) suggested that 'to prevent the full development of the disease (asbestosis) among workers within the space of an average working life-time, it is necessary to reduce the concentration of dust in the air of the workroom to a figure below that pertaining to spinning at the time over which the cases (i.e., those dealt with in the Asbestos Report) were exposed'. To implement the practical application of this principle the asbestos industry in 193I collaborated with the Factories Department (then in the Home Office, now in the Department of Employment and Productivity) in devising methods of dust control. As a result, it was agreed that the conditions arising from flyer spinning, carried on without exhaust, but under good conditions of room ventilation, should be taken as 'dust datum' for practical purposes (Report on Conferences between Employers and Inspectors, 1931). This level of dust production was accepted as the basis on which to assess the dustiness of other processes, and it is of interest to note that in 1956 Meiklejohn considered that nothing had emerged to suggest the need to depart from this practical standard.

The principal methods laid down to achieve dust control are:

(a) application of exhaust draught at dustproducing points;

(b) installation of enclosed mechanical methods for hand conveyance;

(c) effective enclosure of dust-producing machines and plant; and

(d) substitution of wet methods for dry. In situations where these methods cannot be applied, respirators must be worn.

The regulations were made in 1931 to come into force by stages during 1932; we have, therefore, regarded January I, I933, as the commencing date for workers whose mortality can be related to the 
improved conditions. The technical developments necessary for effective dust control were not immediately available, and much research and experiment were needed. Comprehensive accounts of the development of dust control have been given elsewhere by Bamblin (1959) and Hills (1965).

\section{Measurement of Exposure}

The type of asbestos that has been used predominantly is chrysotile, which has been imported mainly from Rhodesia and Swaziland. No workers in the factory were exposed exclusively to crocidolite for any considerable part of their working life. It cannot be affirmed that any were not exposed to it at all, but the amount of exposure must have been relatively small.

It is not possible to obtain a single evaluation of the total hazard to which the workers have been exposed by relating time of exposure to dust level in the working area. One man began to be exposed at the end of the nineteenth century and dust records are not available until 195I. The changes made since I93 I have resulted in a steady improvement in working conditions, and the dust concentration has not been constant in any area.

In 1933, ventilation systems were introduced in carding and weaving. In 1939, damping techniques were established in addition in the weaving process; the improvement was considerable and the conditions of this process have remained reasonably constant from that time to the present day. In 1942, the dust settling chambers in the ventilation system were replaced by cotton fabric sleeve filters. This immediately removed the need for the hazardous operation of cleaning out the chambers. The years immediately following the war saw many other changes. Damping was extended to yarn doubling, and in the period 1953-57 the design of the card extraction system was improved. During this period, oiling of the fibre was introduced at the mixing stage to suppress dust during its subsequent processing. ${ }^{1}$ Before 1958, fibre had been blended on an open floor under dust exhaust hoods, but at this time an entirely new and totally enclosed system, covering the whole fiberizing process before carding, came into operation; and it became possible to add the optimum amount of oil necessary for dust suppression, which had not been possible on the old mixing floor.

\footnotetext{
${ }^{1}$ The oil used is a white mineral textile oil (Besconus, Shell), solvent refined with low aromatic content; viscosity (Redwood) $30-60$ sec. at $70^{\circ} \mathrm{F}$., specific gravity 0.885 at $60^{\circ} \mathrm{F}$.
}

Various methods of dust sampling were used at irregular intervals until I95I when routine dust sampling in the principal parts of the factory was introduced. The Casella Thermal Precipitator instrument was used and the samples were incinerated before being counted at a magnification of $\times 1,000$; all visible particles were counted. This system was in use until 1960, and was invaluable in assisting the engineers in the many improvements then being made. Unfortunately, while particles were included down to the limit of visibility ( 0.2 micron), the instrument was not efficient in capturing the large fibres (above ro microns long), and these fibres were not generally seen in the dust deposited on the counting slides. The Long Running Thermal Precipitator, which collected the sample by a combination of settlement and thermal precipitation, was therefore adopted. Counting was done without incineration at a magnification of $\times 500$ and only those fibres were counted which were between 5 and 100 microns long and whose length was at least three times the diameter. Correlation between the two sets of results proved difficult because the new fibre count was in a sector of the dust spectrum only partly included by the old sampling method. A subsequent change in 1965 from the Long Running Thermal Precipitator to cellulose membrane sampling did not introduce any further complication, as the results, when the new method was properly established, were directly comparable with those obtained previously.

Table I shows average dust levels in parts of the factory where different processes were carried out at the beginning (1952) and the end (1960) of the Casella Thermal Precipitator period, at the beginning of the Long Running Thermal Precipitator period, and with the cellulose membrane fibre counters at the end of the period under observation. There were considerable deviations from the mean figures from time to time, a typical figure for the coefficient of variation in the 1966 data being $40 \%$. The location of the process itself was in some cases changed during the period under review, and sampling points have also changed over the years. It should be noted that sampling, in the past, was geared to the engineering work in progress and not specifically directed towards an assessment of the biological hazard.

The fibre count figures in the Table have been rounded off to the nearest fibre per c.c. These show that considerable improvements were made in the period 1952 to 1960 , during which time the factory was modernized. Since then conditions have remained fairly steady, although work on dust control has continued. In particular, engineering 
TABLE I

Dust Levels accompanying Different Textile Processes, 1952-1966

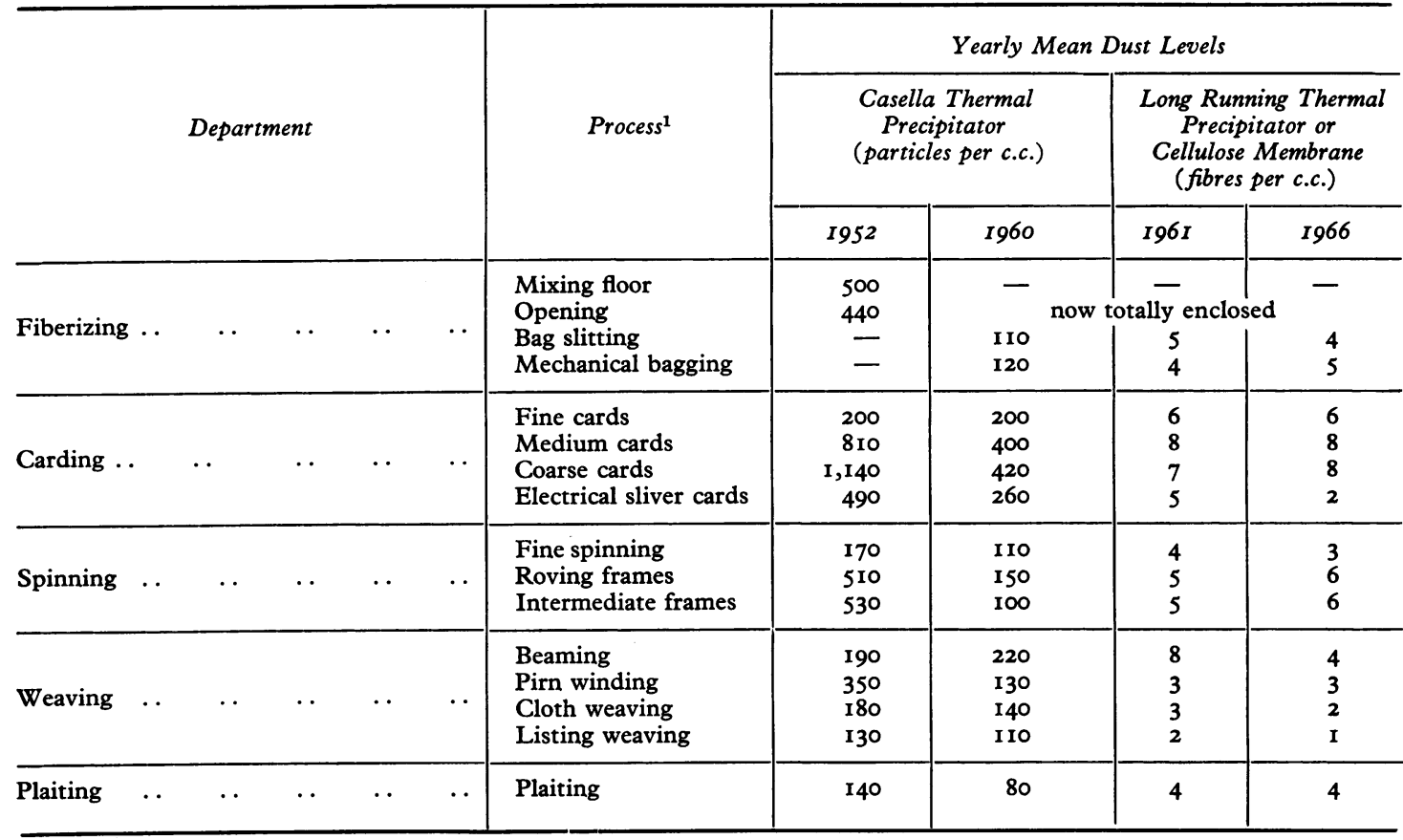

'Constituting all the processes in the 'scheduled areas'.

changes at the Electrical Sliver Cards and at Beaming have had an appreciable effect in reducing fibre counts. Consistently low figures have been obtained at Weaving, and the levels at Listing Weaving have been the lowest in the scheduled areas of the factory.

\section{Mortality Experience}

The study has been confined to observations on men and women who were employed in the scheduled areas. All men are included who were employed in these areas for more than 20 years at any time since the factory opened, and men and women who were employed for more than ro years are also included if they were first employed on or after January I, 1933. Altogether 878 workers have been studied, and the observations extend over a 50 -year period from $1916^{1}$ to the end of June 1966. The numbers of men and women studied and the

IIn Doll's (I955) study the period of observation started from 1922. Further investigation has now shown that one man completed 20 years' employment in what were subsequently scheduled areas in 1916. number of person-years observed are shown in Table II, grouped according to the total duration of exposure, and duration of exposure before January $I$, 1933. Men in group 4 (IO-I9 years' exposure, none before 1933) were transferred to group 3 (20 or more years' exposure, none before 1933) when they

TABLE II

Number of Workers and Number of Person-years at Risk IN Different Exposure Categories

\begin{tabular}{c|c|c|c|c|c}
\hline Group & Sex & $\begin{array}{c}\text { Duration } \\
\text { of } \\
\text { Exposure } \\
\text { in } \\
\text { Scheduled } \\
\text { Areas }(y r s)\end{array}$ & $\begin{array}{c}\text { Duration } \\
\text { of } \\
\text { Exposure } \\
\text { before } \\
1933 \\
(y r s)\end{array}$ & $\begin{array}{c}\text { No. of } \\
\text { Workers }\end{array}$ & $\begin{array}{c}\text { No. of } \\
\text { Person- } \\
\text { years } \\
\text { at Risk }\end{array}$ \\
\hline I & M & 20 or more & Io or more & 57 & 918 \\
2 & M & 20 or more & less than 10 & 63 & 984 \\
3 & M & 20 or more & none & 136 & 621 \\
4 & M & I0-19 & none & 5381 & 4,388 \\
5 & F & I0 or more & none & 220 & 2,263 \\
\hline
\end{tabular}

${ }^{1}$ Including the 136 men in group 3 before they had worked for 20 years in the scheduled areas. 
had completed 20 years in the scheduled areas. The person-years that they contributed while in group 4 remain with group 4, but as from the date of transfer they start contributing to group 3 instead. The person-years in Table II are therefore additive, but the number of workers is not additive since all the 136 men of group 3 have passed through group 4 , and are included in its total of $538 \mathrm{men}$.

The personnel records of the company were used to decide who fulfilled the criteria for inclusion, and the Personnel Department carried out the subsequent follow-up. This was relatively simple for the men who had been exposed for 20 years since they either continued working for the company, or were in receipt of a pension until their death. Follow-up of workers who had been employed in the scheduled areas for less than 20 years was more difficult as some had ceased being employed by the company and had not received a pension. All but one man and one woman, however, were successfully traced. Death entries could not be found for the untraced employees at Somerset House, and for the purpose of the present analysis they have been assumed to be alive.

For each of the five groups a three-dimensional table of person-years at risk was constructed, the dimensions being age of the subject, calendar year, and duration of time since the subject entered the survey, using a five-year grouping for each scale. The numbers of person-years were then multiplied by the corresponding national death rates for various causes and the products summed to give the numbers of deaths expected for comparison with the numbers observed.

The computer program for this purpose was written in Hill's (1968) 'Man Years Computer Language' and the calculations were made on the London University Atlas. National death rates for selected causes for quinquennia up to $1956-60$ were taken from Case and Pearson's (1957, 1963) tables. Outside the range of these tables, quinquennial death rates were compiled from the annual reports of the Registrar-General; 1961-65 rates were used to estimate the numbers of deaths expected in the first half of 1966.

In previous studies the causes of death were mostly obtained from post-mortem reports and the records of the medical department of the company. Death certificates were obtained only when the cause was in doubt or not known. In the present study death certificates have been obtained relating to all deaths but one (which occurred abroad), and the causes of death have been classified in two ways: first, according to the cause given on the death certificate using the method of classification in use by the Registrar-General at the relevant period, and, secondly, according to the best information obtainable from all sources.

Table III shows the observed numbers of deaths classified according to the certified cause in comparison with those expected from national rates. As previously reported, the men who were exposed for Io or more years before 1933 (group I) are shown to have had a highly significant excess of deaths from lung cancer and also from diseases of the circulatory and respiratory systems. In three instances cancer of the lung was discovered post mortem but was not mentioned on the death certificate; these deaths have not been attributed to lung cancer as it is not now possible to discover whether the information was reported to the Registrar General. ${ }^{1}$ The small excess of deaths due to other neoplasms is not statistically significant. It may be noted, however-in view of the finding of an excess mortality from gastro-intestinal cancer in insulation workers who were regularly exposed to asbestos in the United States of America (Selikoff, Churg, and Hammond, 1964)-that the five deaths were attributed respectively to cancer of the stomach (I), colon (2), gall-bladder (I), and prostate (I).

A significant excess of deaths from lung cancer is recorded also among men who worked in the scheduled areas before 1933 but for less than Io years (group 2). The ratio of observed to expected deaths $(3 \cdot 2: 1)$ is, however, much smaller than for men who were exposed for Io or more years (IO-2:I). In addition to the five men whose deaths were attributed to lung cancer, one other man, whose death was certified as due to myocardial degeneration, was found to have cancer of the lung post mortem. ${ }^{2}$ The number of deaths from diseases of the circulatory and respiratory systems (II) is only slightly greater than the expected number (7.94); asbestosis was, however, mentioned on nearly half of the death certificates ( 5 out of II).

Among men and women who have worked in the scheduled areas only since I933 (groups 3,4 , and 5) the observed mortality from all causes is close to the expected (79 against $8 \mathrm{I} \cdot 05$ ). The total observed experience is substantial, and the result provides grounds for believing that the occupational hazard has been largely eliminated. Four facts, however,

\footnotetext{
1 These deaths were attributed to lung cancer in previous reports (Doll, 1955; Knox et al., 1965; Hill et al., 1966).
}

'Death attributed to lung cancer in previous reports. 
TABLE III

Numbers of Deaths Observed and Expected, by Exposure Catrgory and Cause

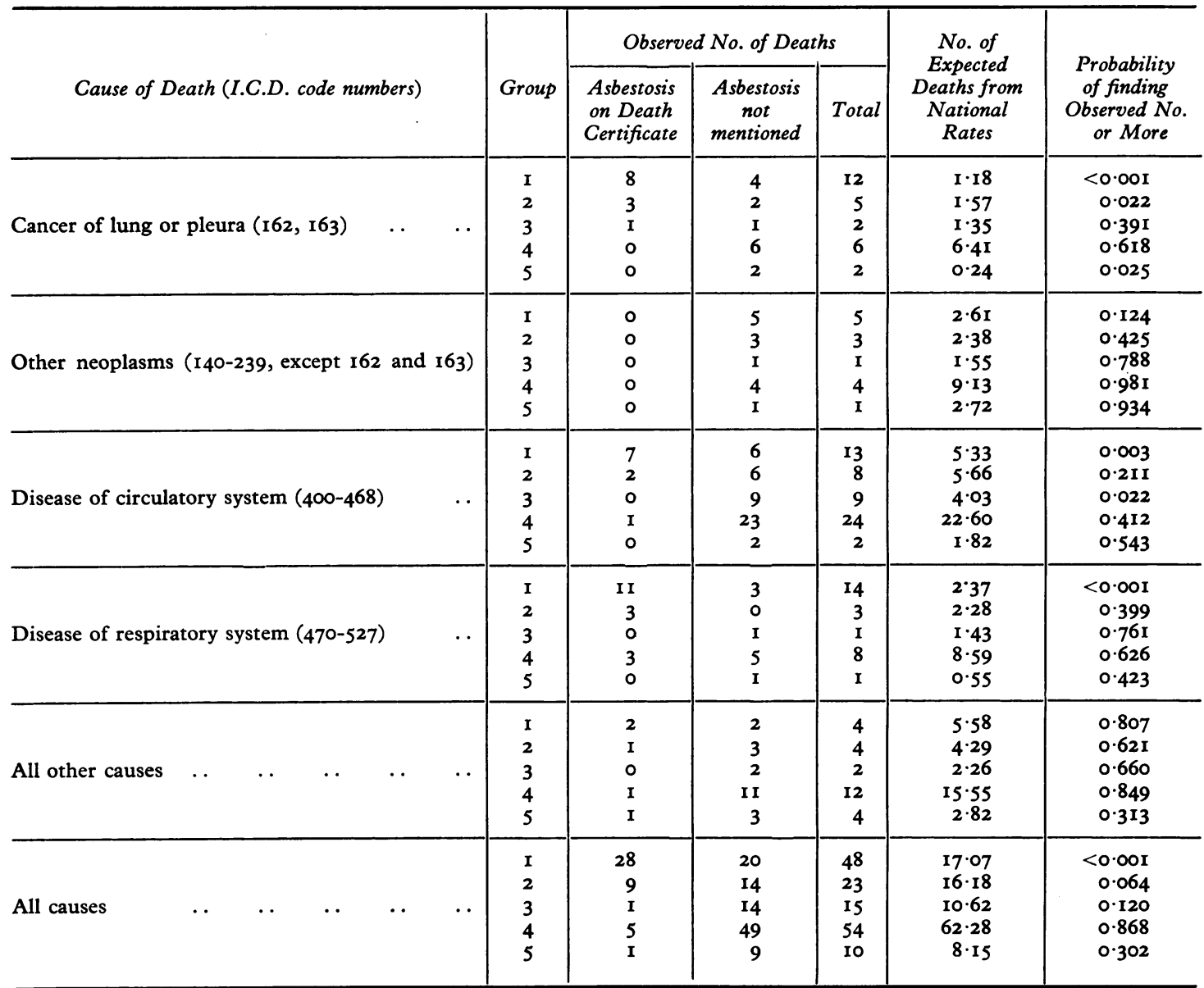

suggest that it is necessary to suspend judgement about the extent of the risk that may still remain. First, asbestosis was mentioned on the death certificate in seven instances. Secondly, the observations on men who have worked in the scheduled areas for more than 20 years (group 3 ) are few, and previous experience has shown that the risk of lung cancer is relatively small until after 20 years' exposure. Thirdly, the ratio of all observed to expected deaths in men in group 3 $(I \cdot 4: I)$ is the same as in men who were exposed before 1933, but for less than Io years (group 2). Fourthly, two deaths from lung cancer occurred in women-an unexpected observation in view of the rarity of the disease in women in the country as a whole $(P=0.025)$.
One explanation of this last finding may be that women who work in factories smoke more than other women of the same ages, so that the national mortality rates provide an unsuitable standard for assessing the existence of a specific occupational hazard. One of the two women who died of lung cancer, however, was a non-smoker.

The only other notable finding is the excess of deaths from diseases of the circulatory system in men who had worked for 20 years in the scheduled areas, but only since I933 (9 deaths against 4.03 expected). None of the men were known to have had asbestosis and the group showed no corresponding excess of deaths from respiratory disease. It seems probable, therefore, that this is a chance finding of no medical importance $(P=0.022$, 
one-tail test), but the possibility of a continuing hazard must be borne in mind.

One of the difficulties in interpreting these results is that duration of employment before 1933 is closely correlated with the duration of observation and the individual worker's age, both of which may be related to the risk of developing disease. An analysis has, therefore, been made of the trends in mortality in relation to each of these factors after standardizing for the other two. The analysis has been limited to men who were employed for 20 or more years (groups 1,2 , and 3) and the expected numbers of deaths have been calculated for each cell of the three-dimensional table formed by three exposure groups (more than ro years before 1933, some exposure before 1933 but less than Io years, and no exposure before 1933); six duration of observation groups (0-4 years to 25-29 years after completing 20 years' exposure); and ro five-year age groups (30-34 years to 75-79 years). The analysis has been made separately for three categories of death (lung cancer, other causes with asbestosis, and other causes without asbestosis), and for this purpose-since the comparisons are entirely within the series and not with national mortality data-we have classified death as being due to lung cancer whenever the disease was diagnosed at necropsy, irrespective of the diagnosis on the certificate. The total number of lung cancer deaths available for analysis is, therefore, 23. In these Tables, it will be noted, the 'expected' numbers are derived from the experience of the workers studied as a whole and bear no relation to the 'expected' numbers in Table III which are derived from national death rates. The results show: (I) a statistically significant reduction in mortality from lung cancer, and other diseases with asbestosis, with reduction in length of exposure before 1933 (Table IV); (2) a highly significant increase in mortality from lung cancer and other diseases without asbestosis with increase in age at exposure (Table V); and (3) no evidence of a change in mortality for any causes of death with the passage of time after completion of 20 years' work in the scheduled areas (Table VI).

These results are, in large part, those that would be expected if exposure to asbestos dust was responsible for a substantial proportion of the deaths from lung cancer and from other diseases with asbestosis but was unrelated to other diseases without asbestosis. They confirm that there has been a significant decrease in the occupational hazards since 1932.

Two other findings call for comment. First, the trend in the mortality from lung cancer with age at exposure accords with some other human data, but is contrary to the conclusions that have been drawn from animal experiments (Doll, 1964). In part it may be due to the inclusion of four or five cases due to other and non-occupational causes. Secondly, it is surprising to find that, after standardization for age, neither the mortality from lung cancer nor the mortality from other diseases with asbestosis increases with the passage of time after the completion of 20 years' work in the scheduled areas. It must be remembered, however, that exposure to asbestos dust has changed at irregular intervals throughout the whole period of observation and the crude classification of exposures into three groups according to the length of employment before I933 cannot adequately allow for these changes. How this has biased the results

TABLE IV

Distribution of Deaths With EXPosure before 1933

Standardized for Time since Completing 20 Years' Employment and Age

\begin{tabular}{|c|c|c|c|c|c|c|c|}
\hline \multirow{2}{*}{\multicolumn{2}{|c|}{ Exposure before I933 (yrs) }} & \multicolumn{2}{|c|}{$\begin{array}{c}\text { Distribution of } \\
\text { Lung Cancer } \\
\text { Deaths }\end{array}$} & \multicolumn{2}{|c|}{$\begin{array}{l}\text { Distribution of } \\
\text { Other Deaths } \\
\text { with Asbestosis }\end{array}$} & \multicolumn{2}{|c|}{$\begin{array}{l}\text { Distribution of } \\
\text { Other Deaths } \\
\text { without Asbestosis }\end{array}$} \\
\hline & & Observed & Expected & Observed & Expected & Observed & Expected \\
\hline $\begin{array}{l}\text { Over Io (group I) } \\
\text { Up to Io (group 2) } \\
\text { None (group 3) }\end{array}$ & $\begin{array}{l}\cdots \\
\cdots \\
\cdots\end{array}$ & $\begin{array}{r}15 \\
6 \\
2\end{array}$ & $\begin{array}{l}9 \cdot 81 \\
8 \cdot 41 \\
4 \cdot 78\end{array}$ & $\begin{array}{r}17 \\
5 \\
0\end{array}$ & $\begin{array}{r}11 \cdot 38 \\
8 \cdot 07 \\
2.55\end{array}$ & $\begin{array}{l}16 \\
12 \\
13\end{array}$ & $\begin{array}{l}16 \cdot 91 \\
12 \cdot 98 \\
11 \cdot 12\end{array}$ \\
\hline All groups & .. & 23 & $23 \cdot 00$ & 22 & $22 \cdot 00$ & $4 I$ & $4 I \cdot 0 I$ \\
\hline \multicolumn{2}{|c|}{ Test of significance of trend } & \multicolumn{2}{|c|}{$\begin{aligned} x^{2} & =6.70 \\
\mathrm{n} & =\mathrm{I} \\
\mathrm{P} & =0.01\end{aligned}$} & \multicolumn{2}{|c|}{$\begin{aligned} x^{2} & =9.63 \\
\mathrm{n} & =\mathrm{r} \\
\mathrm{P} & =0.002\end{aligned}$} & \multicolumn{2}{|c|}{$\begin{aligned} x^{2} & =0.52 \\
\mathrm{n} & =\mathrm{I} \\
\mathrm{P} & =0.47\end{aligned}$} \\
\hline
\end{tabular}


TABLE V

Distribution of Deaths with Age

Standardized for Period of Exposure and Time since Completing 20 Years' Employment

\begin{tabular}{|c|c|c|c|c|c|c|c|}
\hline \multirow{2}{*}{\multicolumn{2}{|c|}{$\operatorname{Age}(y r s)$}} & \multicolumn{2}{|c|}{$\begin{array}{l}\text { Distribution of } \\
\text { Lung Cancer } \\
\text { Deaths }\end{array}$} & \multicolumn{2}{|c|}{$\begin{array}{l}\text { Distribution of } \\
\text { Other Deaths } \\
\text { with Asbestosis }\end{array}$} & \multicolumn{2}{|c|}{$\begin{array}{l}\text { Distribution of } \\
\text { Other Deaths } \\
\text { without Asbestosis }\end{array}$} \\
\hline & & Observed & Expected & Observed & Expected & Observed & Expected \\
\hline & $\begin{array}{l}30-34 \\
35-39 \\
40-44 \\
45-49 \\
50-54 \\
55-59 \\
60-64 \\
65-69 \\
70-74 \\
75-79\end{array}$ & $\begin{array}{l}0 \\
0 \\
0 \\
2 \\
5 \\
4 \\
6 \\
3 \\
3 \\
0\end{array}$ & $\begin{array}{l}0.03 \\
0.36 \\
1.45 \\
4.00 \\
5.79 \\
4.66 \\
3.13 \\
2.45 \\
1.09 \\
0.04\end{array}$ & $\begin{array}{l}0 \\
1 \\
2 \\
1 \\
1 \\
7 \\
6 \\
2 \\
2 \\
0\end{array}$ & $\begin{array}{l}0.03 \\
0.37 \\
1.52 \\
3.39 \\
4.53 \\
4.45 \\
3.48 \\
2.70 \\
1.33 \\
0.20\end{array}$ & $\begin{array}{r}0 \\
0 \\
0 \\
2 \\
5 \\
10 \\
9 \\
10 \\
3 \\
2\end{array}$ & $\begin{array}{l}0.01 \\
0.26 \\
1.80 \\
4.56 \\
8.45 \\
9.52 \\
8.96 \\
5.57 \\
1.59 \\
0.27\end{array}$ \\
\hline All ages & $\begin{array}{lll}\ldots & \ldots & \ldots\end{array}$ & 23 & $23 \cdot 00$ & 22 & $22 \cdot 00$ & $4 I$ & $40 \cdot 99$ \\
\hline Test of si & ificance of trend ... & \multicolumn{2}{|c|}{$\begin{array}{l}x^{2}=12 \cdot 12 \\
n=1 \\
P<0.001\end{array}$} & \multicolumn{2}{|c|}{$\begin{aligned} x^{2} & =1 \cdot 46 \\
\mathrm{n} & =\mathrm{I} \\
\mathrm{P} & =0.23\end{aligned}$} & \multicolumn{2}{|c|}{$\begin{array}{l}x^{2}=20 \cdot 48 \\
\mathrm{n}=\mathrm{I} \\
\mathrm{P}<0.001\end{array}$} \\
\hline
\end{tabular}

TABLE VI

Distribution of Deaths with Time since Completing 20 Years' Employment Standardized for PERIOd OF EXPOSURE aNd AGE

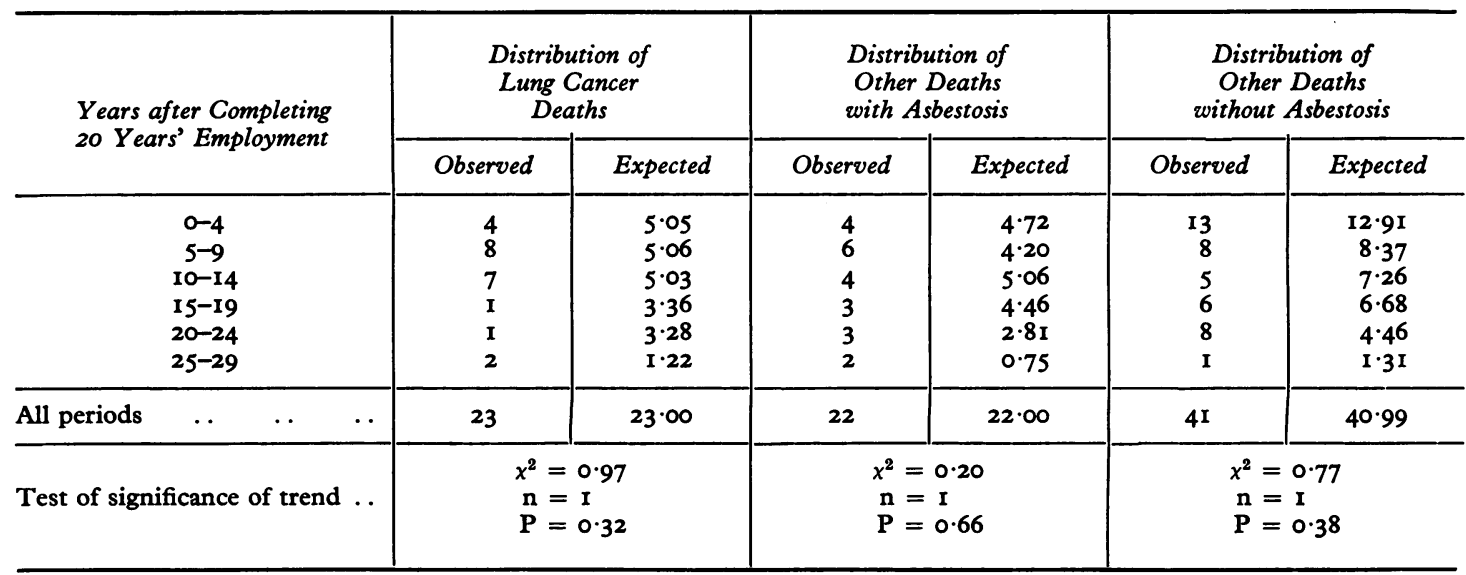

is not clear, but it emphasizes the need for caution in interpreting the trends with age and duration of observation.

\section{Types of Lung Tumour}

Details of the occupational histories of the 23 men who had been employed for 20 or more years in the scheduled areas and who developed lung tumours are given in Table VII, along with the pathological diagnoses. Twenty-one of the cases were confirmed at necropsy and 22 by histological examination. All but one of the tumours were regarded as bronchial carcinomas, indistinguishable from the type of tumour that has occurred commonly in the general population during the last 30 years. The exception was diagnosed as 'endothelioma of the pleura' in 1936. The expected number of lung 
TABLE VII

Occupational and Pathological Data Relating to Men Dying with lung Cancer: Men Employed for 20 Years or More IN SCHEDUled AREAS

\begin{tabular}{|c|c|c|c|c|c|c|c|c|c|c|c|c|}
\hline \multirow[b]{2}{*}{$\begin{array}{l}\text { Year } \\
\text { of } \\
\text { Death }\end{array}$} & \multirow[b]{2}{*}{$\begin{array}{l}\text { Age } \\
\text { (yrs) }\end{array}$} & \multirow[b]{2}{*}{ Occupation } & \multirow{2}{*}{$\begin{array}{l}\text { Period } \\
\text { of } \\
\text { Exposure }\end{array}$} & \multicolumn{4}{|c|}{ Duration of Exposure $(y r s)^{2}$} & \multicolumn{2}{|c|}{ Necropsy } & \multicolumn{2}{|c|}{ Death Certificate } & \multirow[b]{2}{*}{$\begin{array}{l}\text { Histology of } \\
\text { Tumour }\end{array}$} \\
\hline & & & & Total & $\begin{array}{c}\text { Before } \\
\text { fan. I } \\
1933\end{array}$ & $\begin{array}{c}\text { From } \\
\text { Beginning } \\
\text { to } \\
\text { Death }\end{array}$ & $\mid \begin{array}{c}\text { From } \\
\text { End } \\
\text { to } \\
\text { Death }\end{array}$ & $\begin{array}{c}\text { Per- } \\
\text { formed }\end{array}$ & $\begin{array}{c}\text { Asbest- } \\
\text { osis } \\
\text { Present }\end{array}$ & $\begin{array}{c}\text { Asbest- } \\
\text { osis } \\
\text { Men- } \\
\text { tioned }\end{array}$ & $\begin{array}{l}\text { Attributed } \\
\text { Cause of } \\
\text { Death }\end{array}$ & \\
\hline 1935 & 54 & Weaver & $1909-32$ & 23 & 23 & 26 & 2 & + & + & + & $\begin{array}{l}\text { Cardiac failure and } \\
\text { pericarditis }\end{array}$ & Epithelioma \\
\hline 1936 & 65 & Fiberizer & $1913-36$ & 22 & 19 & 23 & $<\mathbf{I}$ & + & + & + & $\begin{array}{l}\text { Endothelioma of } \\
\text { pleura }\end{array}$ & $\begin{array}{l}\text { Endothelioma of } \\
\text { pleura }\end{array}$ \\
\hline 1939 & 49 & Disintegrator & $\left\{\begin{array}{l}1910-14 \\
1919-39\end{array}\right.$ & 23 & 17 & 28 & $<\mathrm{I}$ & + & + & $\circ$ & $\begin{array}{l}\text { Carcinoma of } \\
\text { lung }\end{array}$ & Carcinoma \\
\hline 1940 & 52 & Disintegrator & $\left\{\begin{array}{l}1911-15 \\
1919-21 \\
1923-39\end{array}\right.$ & 21 & 15 & 29 & $<\mathrm{I}$ & + & + & + & $\begin{array}{l}\text { Carcinoma of } \\
\text { lung }\end{array}$ & Carcinoma \\
\hline $194 \mathrm{I}$ & 52 & Weaver & $\left\{\begin{array}{l}1913-19 \\
1924-38\end{array}\right.$ & 21 & 15 & 28 & 2 & + & + & + & $\begin{array}{l}\text { Carcinoma of } \\
\text { lung }\end{array}$ & Oat-cell carcinoma \\
\hline 1942 & 59 & Bag carrier & $1913-41$ & 28 & 19 & 29 & $<\mathbf{I}$ & + & + & + & $\begin{array}{l}\text { Pulmonary } \\
\text { carcinoma }\end{array}$ & Oat-cell carcinoma \\
\hline 1948 & 59 & Weaver & $\left\{\begin{array}{l}1912-14 \\
1918-48\end{array}\right.$ & 32 & 16 & 35 & $<\mathrm{I}$ & + & + & + & Asbestosis & $\begin{array}{l}\text { Anaplastic } \\
\text { carcinoma }\end{array}$ \\
\hline 1948 & 48 & Spinner & $1922-48$ & 26 & ro & 26 & $<\mathbf{I}$ & + & + & $\begin{array}{l}0 \\
i\end{array}$ & $\begin{array}{l}\text { Carcinoma of } \\
\text { lung }\end{array}$ & Carcinoma \\
\hline 1948 & 65 & Maintenance & $1919-48$ & 29 & 13 & 29 & $<\mathrm{I}$ & + & + & $\dot{t}$ & Tuberculosis & Oat-cell carcinoma \\
\hline 1951 & 74 & Fiberizer & $1917-43$ & 26 & 15 & 34 & 7 & + & + & + & $\begin{array}{l}\text { Carcinoma of } \\
\text { lung }\end{array}$ & Adenocarcinoma \\
\hline 1951 & 60 & Weaver & $\left\{\begin{array}{l}1919-25 \\
1929-50\end{array}\right.$ & 26 & 9 & 31 & $\mathbf{I}$ & + & + & + & Myocarditis & Carcinoma \\
\hline 1954 & 53 & Weaver & $1923-49$ & 25 & 9 & $3 I$ & 5 & + & + & + & $\begin{array}{l}\text { Carcinoma of } \\
\text { lung }\end{array}$ & Epithelioma \\
\hline 1956 & 67 & Spinner & $1915-48$ & 32 & 17 & 40 & 7 & + & + & $\circ$ & $\begin{array}{l}\text { Carcinoma of } \\
\text { lung }\end{array}$ & Adenocarcinoma \\
\hline 1956 & 63 & Weaver & $\left\{\begin{array}{l}1912-14 \\
1919-41\end{array}\right.$ & 24 & 16 & 44 & 15 & + & + & + & $\begin{array}{l}\text { Carcinoma of } \\
\text { lung }\end{array}$ & Carcinoma \\
\hline 1956 & 55 & Braider & $\left\{\begin{array}{l}1914-19 \\
1932-56\end{array}\right.$ & 29 & 6 & 42 & $<\mathrm{I}$ & + & 0 & $\circ$ & $\begin{array}{l}\text { Bronchogenic } \\
\text { carcinoma }\end{array}$ & Oat-cell carcinoma \\
\hline 1956 & 55 & Fiberizer & $1924-48$ & 24 & 8 & 32 & 8 & + & + & + & $\begin{array}{l}\text { Carcinoma of } \\
\text { lung }\end{array}$ & Carcinoma \\
\hline 1956 & $6 I$ & Weaver & $1923-51$ & 28 & 9 & 32 & 4 & + & + & + & $\begin{array}{l}\text { Carcinoma of } \\
\text { lung }\end{array}$ & Oat-cell carcinoma \\
\hline 1957 & 74 & Beamer & $\left\{\begin{array}{l}1911-19 \\
1919-50 \\
1951-51\end{array}\right.$ & 39 & $2 \mathrm{I}$ & 46 & 6 & + & + & + & $\begin{array}{l}\text { Carcinoma of } \\
\text { lung and pleura }\end{array}$ & Carcinoma \\
\hline 1958 & 71 & Weaver & $1911-47$ & 35 & $2 \mathbf{I}$ & 47 & I I & $\circ$ & N.A. & o & $\begin{array}{l}\text { Carcinoma of } \\
\text { lung }\end{array}$ & \\
\hline 1960 & 62 & Weaver & $\left\{\begin{array}{l}1920-33 \\
1940-47\end{array}\right.$ & 20 & 12 & 40 & 12 & + & + & + & $\begin{array}{l}\text { Carcinoma of } \\
\text { lung }\end{array}$ & $\begin{array}{l}\text { Large-cell } \\
\text { adenocarcinoma }\end{array}$ \\
\hline 1963 & 54 & Weaver & $\left\{\begin{array}{l}1929-45 \\
1946-63\end{array}\right.$ & 33 & 3 & 34 & $<\mathbf{I}$ & 0 & N.A. & 0 & $\begin{array}{l}\text { Carcinoma of } \\
\text { bronchus }\end{array}$ & $\begin{array}{l}\text { Adenocarcinoma } \\
\text { (biopsy) }\end{array}$ \\
\hline 1963 & 58 & Beamer & $\left\{\begin{array}{l}1935-37 \\
1939-59\end{array}\right.$ & 21 & ० & 27 & 3 & + & + & + & $\begin{array}{l}\text { Carcinoma of } \\
\text { bronchus }\end{array}$ & Carcinoma \\
\hline 1966 & 61 & Weaver & $1939-66$ & 26 & $\circ$ & 26 & $<\mathrm{I}$ & + & 0 & 0 & $\begin{array}{l}\text { Carcinoma of } \\
\text { bronchus }\end{array}$ & Carcinoma \\
\hline
\end{tabular}

${ }^{1}$ Incorporating data from Table 2 in Doll's (1955) paper.

${ }^{2}$ Completed years; as a result the sum of the total exposure and the duration from last exposure to death may be less than the duration from first exposure to death, even if the period of exposure was unbroken. 
tumours is estimated to have been about four (Table III) or perhaps somewhat more as a high proportion of men who died with respiratory symptoms came to necropsy (see 'mortality experience' page 296 and Doll, 1955). The excess number of deaths from this cause is, therefore, about 19, of which one can be attributed to a pleural mesothelioma and about 18 to bronchial carcinoma.

Awareness of pleural mesothelioma as a separate oncological entity has increased greatly in recent years, particularly since Wagner, Sleggs, and Marchand (1960) drew attention to its characteristic association with exposure to crocidolite asbestos. The possibility must, therefore, be considered that some pleural mesotheliomas have been misclassified as bronchial carcinomas. In our view this is unlikely to have occurred. In nearly every case the tumours classified as bronchial carcinomas were found to have their origin in the substance of the lung at necropsy and were readily identified by their microscopic appearances. ${ }^{1}$ Moreover, it may be noted that the distribution of cases of bronchial carcinoma and pleural mesothelioma is not dissimilar from that reported by Selikoff, Hammond, and Churg (1967) among members of the International Association of Heat and Frost Insulators and Asbestos Workers who had first been exposed to asbestos dust more than 20 years previously. In the study by Selikoff and his

\footnotetext{
${ }^{1}$ Including the man shown in Table VII as dying of carcinoma of the lung and pleura in 1957.
}

colleagues, which covered the period 1962-67, 24 deaths were attributed to bronchial carcinoma against $2 \cdot 3$ expected and 3 were attributed to pleural mesothelioma out of a total of 94 deaths from all causes.

Since 1935, when the first death from lung cancer in our series was reported, records have also been kept of all coroners' necropsies on men and women known to have been employed at the factory. ${ }^{2}$ Review of these records revealed four other cases which have been accepted as mesothelioma of the pleura by Dr. J. C. Wagner. Occupational histories and other data relating to the five men and women who developed mesothelioma are summarized in Table VIII. Only one man among these had been employed in the scheduled area for more than Io years. Three died more than 40 years after first exposure to asbestos and one of these had been employed in the factory less than one year. From previous experience (Doll, 1955), it appears that the specific risk of bronchial carcinoma is relatively small with less than 20 years' exposure so that the contrast with pleural mesothelioma in these data is marked. Follow-up information has not been obtained for all men and women who have ever been employed in the scheduled areas, so that it is not now possible to make any accurate estimates of mortality. It is known, however, that over 12,000

${ }^{2}$ Necropsies on asbestos workers are ordered by the coroner whenever there is, in his opinion, a question of an industrial origin of death.

TABLE VIII

Occupational and Pathological Data relating to Asbestos Workers Dying with Pleural Mesothelioma: ALl EMPLOYEeS

\begin{tabular}{|c|c|c|c|c|c|c|c|c|c|c|c|c|}
\hline \multirow{2}{*}{$\begin{array}{c}\text { Year } \\
\text { of } \\
\text { Death }\end{array}$} & \multirow[b]{2}{*}{ Sex } & \multirow[b]{2}{*}{$\begin{array}{l}\text { Age } \\
\text { (yrs) }\end{array}$} & \multirow[b]{2}{*}{ Occupation } & \multirow{2}{*}{$\begin{array}{l}\text { Period } \\
\text { of } \\
\text { Exposure }\end{array}$} & \multicolumn{4}{|c|}{ Duration of Exposure ( $y r s)$} & \multicolumn{2}{|c|}{ Necropsy } & \multicolumn{2}{|c|}{ Death Certificate } \\
\hline & & & & & Total & $\begin{array}{c}\text { Before } \\
\text { Fan. I } \\
\text { I933 }\end{array}$ & $\begin{array}{c}\text { From } \\
\text { Begin- } \\
\text { ning to } \\
\text { Death }\end{array}$ & $\begin{array}{c}\text { From } \\
\text { End } \\
\text { to } \\
\text { Death }\end{array}$ & $\begin{array}{c}\text { Per- } \\
\text { formed }\end{array}$ & $\begin{array}{l}\text { Asbest- } \\
\text { osis } \\
\text { Present }\end{array}$ & $\begin{array}{c}\text { Asbest- } \\
\text { osis } \\
\text { Men- } \\
\text { tioned }\end{array}$ & $\begin{array}{l}\text { Attributed Cause } \\
\text { of Death }\end{array}$ \\
\hline $1936^{1}$ & $\mathbf{M}$ & 65 & Fiberizer & I913-36 & 23 & 19 & 23 & $<\mathbf{I}$ & + & + & + & Endothelioma of \\
\hline I964 & $\mathbf{M}$ & 57 & $\begin{array}{l}\text { Carder, } \\
\text { spinner }\end{array}$ & $1922-23^{2}$ & $1 \frac{5}{12}$ & $1 \frac{5}{12}$ & 42 & $4 \mathrm{I}$ & + & $\circ$ & + & $\begin{array}{l}\text { Malignant pleural } \\
\text { tumour }\end{array}$ \\
\hline I966 & $\mathbf{F}$ & 55 & $\begin{array}{l}\text { Carder, } \\
\text { spinner }\end{array}$ & $1926-35$ & 9 & 6 & 40 & $3 \mathrm{I}$ & + & $\circ$ & $\circ$ & Carcinoma of lung \\
\hline 1966 & $\mathbf{M}$ & 59 & Weaver & $\left\{\begin{array}{l}1937-38^{3} \\
1960-65\end{array}\right.$ & 6 & 0 & 29 & $\mathbf{I}$ & + & + & + & Carcinoma of lung \\
\hline I967 & $\mathbf{M}$ & 72 & Weaver & $\left\{\begin{array}{l}1914 \\
1919-20\end{array}\right.$ & $0 \frac{2}{12}$ & $0 \frac{7}{12}$ & 53 & 47 & + & $\circ$ & o & $\begin{array}{l}\text { Myeloid leukaemia } \\
\text { (carcinoma of } \\
\text { lung associated) }\end{array}$ \\
\hline
\end{tabular}

${ }^{1}$ Also included in Table VII.

${ }^{2}$ Also employed for 15 years in the rubber department (1929-44) and 20 years in the warehouse (1944-64).

${ }^{3} \mathrm{Also}$ employed in the warehouse, 1929-30. 
workers were employed in the scheduled areas at some period between 1930 and 1952 .

\section{REFERENCES}

Asbestos Industry Regulations (1931). Asbestos Industry Regulations: Statutory Rules and Orders, I93I, No. II 40. H.M.S.O., London.

Bamblin, W. P. (1959). Dust control in the asbestos textile industry. Ann. occup. Hyg., 2, 54-74.

Case, R. A. M., and Pearson, J. T. (I957). Tables for comparative composite cohort analysis. Cancer. In: Cancer statistics for England and Wales, I90I-55: pp. 37-99. General Register Office. Studies on medical and population subjects, No. 13. H.M.S.O., London.

cohort analyses. (Personal communication.)

Doll, R. (1955). Mortality from lung cancer in asbestos workers. Brit. F. industr. Med., 12, 81-86.

- (1964). Epidemiological observations on susceptibility to cancer in man with special reference to age. Acta Un. int. Cancr., 20, 747-752.

Gilson, J. C. (1966). Health hazards of asbestos: recent studies on its biological effects. Trans. Soc. occup. Med., 16, 62-74.

Hill, I. D. (I968). Draft Mycl Manual. To be published. , Doll, R., and Knox, J. F. (1966). Mortality among asbestos workers. Proc. roy. Soc. Med., 59, 59-60.
Hills, D. W. (1965). Economics of dust control. Ann. N.Y. Acad. Sci., 132, 322-334.

Knox, J. F., Doll, R. S., and Hill, I. D. (1965). Cohort analysis of changes in incidence of bronchial carcinoma in a textile asbestos factory. Ibid., 132, 526-535.

Meiklejohn, A. (I956). In: Industrial Medicine and Hygiene. Edited by Merewether, E. R. A., vol. 3, p. II7. Butterworth, London.

Merewether, E. R. A., and Price, C. W. (1930). Report on Effects of Asbestos Dust on the Lungs, and Dust Suppression in the Asbestos Industry. H.M.S.O., London.

New York Academy of Sciences (1965). Biological effects of asbestos. Ann. N.Y. Acad. Sci., 132, I-766.

Report on Conferences between Employers and Inspectors (1931). Report on Conferences between Employers and Inspectors concerning Methods of Suppressing Dust in Asbestos Textile Factories. H.M.S.O., London.

Selikoff, I. J., Churg, J., and Hammond, E. C. (I964). Asbestos exposure and neoplasia. F. Amer. med. Ass., $188,22-26$.

—, Hammond, E. C., and Churg, J. (1967). Asbestos exposure, smoking and neoplasia. Paper read to the section on diseases of the chest and preventive medicine, American Medical Association, Atlantic City, June, 1967.

Wagner, J. C., Sleggs, C. A., and Marchand, P. (I960). Diffuse pleural mesothelioma and asbestos exposure in the North Western Cape Province. Brit. F. industr. Med., 17, 260-27I. 